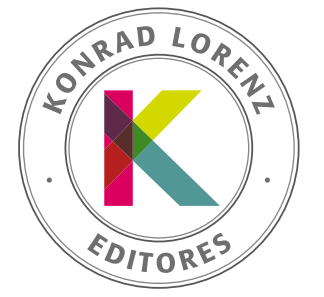

\title{
Psychometric properties of the Dating Violence Questionnaire, (DVQ-8): A screening tool for educational settings
}

\author{
Javier López-Cepero ${ }^{\mathrm{a}, *}$, Cristina Estrada Pinedab, Elsy Claudia Chan-Gamboa ${ }^{\mathrm{b}}$ \\ y Mónica Macías Pérez
}

a Universidad de Sevilla, Sevilla, España

${ }^{b}$ Universidad de Guadalajara, Guadalajara, Jalisco, México

Recibido el 3 de octubre de 2018; aceptado el 11 de marzo de 2019

KEYWORDS

Screening, dating Violence, partner violence, assessment, university students

\begin{abstract}
This article provides psychometric information from a screening tool for victimization in young couples: the 8-Item Dating Violence Questionnaire. The first study undertook an exploratory factor analysis with polymorphic correlation matrices and oblimin rotation of 990 Mexican university students with an average age of 19.5, two thirds of whom were women, obtaining a unifactorial structure with high reliability for males and females. The second study, with a sample of 355 participants, provided information on the validity of the instrument, finding a positive relationship between the 8-Item Dating Violence Questionnaire and perceived victimization. High significance and a large effect size and negative relationship were obtained between the instrument and state of health, with a moderate effect. In conclusion, the DVQ-8 includes reliable, valid indicators for the early detection of victimization in educational settings. (c) 2019 Fundación Universitaria Konrad Lorenz. This is an open access article under the CC BY-NCND license (http://creativecommons.org/licenses/bync-nd/4.0/).
\end{abstract}

\section{Propiedades psicométricas del Cuestionario de Violencia de Pareja, versión corta (DVQ-8): una herramienta de evaluación para entornos educativos}

Resumen Este artículo proporciona información psicométrica de un instrumento de screening de victimización en parejas jóvenes: Dating Violence Questionnaire de 8 ítems. Un primer estudio desarrolló un análisis factorial exploratorio con matrices de correlación policóricas y rotación oblimin con 990 jóvenes universitarios mexicanos con edad promedio de 19.5, de las que dos tercios fueron mujeres, obteniendo una estructura unifactorial con alta confiabilidad para varones y mujeres. El segundo estudio, con una muestra de 355 participantes, proporcionó información sobre la validez del instrumento, encontrando una relación positiva entre el Dating Violence Questionnaire de 8 ítems y victimización percibida, se obtuvieron una significación alta y el tamaño del efecto grande y una relación negativa entre el instrumento

* Autor para correspondencia.

Correo electrónico: jalocebo@us.es

http://dx.doi.org/10.14349/sumapsi.2019.v26.n1.4

0120-0534/@ 2019 Fundación Universitaria Konrad Lorenz. Este es un artículo Open Access bajo la licencia CC BY-NC-ND (http://creativecommons.org/licenses/by-nc-nd/4.0/). 
y estado de salud, con un efecto moderado. En conclusión, el DVQ-8 incluye indicadores confiables y válidos para la detección temprana de victimización en contextos educativos.

(c) 2019 Fundación Universitaria Konrad Lorenz. Este es un artículo Open Access bajo la licencia CC BY-NC-ND (http://creativecommons.org/licenses/bync-nd/4.0/).

The majority of the world's population has engaged, is currently engaged in or will engage in a relationship with at least one sentimental partner during their lifetime. Scientific literature demonstrates the link between the quality of social relations and a variety of benefits for physical and psychological health in both subjective (e.g. life satisfaction) and objective terms (e.g. longevity) (Loving \& Slatcher, 2013; Uchino, 2006). Nevertheless, partner aggression is a common phenomenon, with ample evidence of its presence existing in various geographical regions, in both sexes, with various sexual orientations and within a broad range of ages (for a review, see Desmarais, Reeves, Nichols, Telford \& Fiebert, 2012; Esquivel-Santoveña, Lambert \& Hamel, 2013; Langhinrichsen-Rohling, Misra, Selwyn, \& Rohling, 2012).

In Mexico, several studies on this issue have been undertaken nationwide. Among them, the 2013-2014 State Youth Survey shows that $30 \%$ of young people surveyed, both men and women, suffered some type of violence in courtship, mainly psychological (48\%), with $10 \%$ of respondents suffering physical violence (Instituto Mexiquense de la Juventud, 2013). More recently, the National Survey on the Dynamics of Relations in Households was conducted on a sample of women over 15 . In this survey, the data reveals that $43.9 \%$ of respondents have experienced violence in their current or last relationship (INEGI, 2017). Other studies have been conducted in the region on violence in dating relationships in both the youth (Cortaza, Mazadiego, \& Ruiz 2011, Peña et al., 2013, Sosa \& Menkes, 2016) and the adult population, (López, Moral, Díaz, \& Cienfuegos, 2013) also indicating a high prevalence of violence.

Of all the methods available for evaluating partner violence, behavioural instruments constitute the main source of information for sociology, psychology and social work researchers (Costa \& Barros, 2016). Although there are significant differences in regards to the number of items, typology of violence defined by its scales, groups that may be evaluated (one or both sexes, different or same-sex couples) or assigned roles (aggressive male, female victims) (López-Cepero, Rodríguez-Franco \& Rodríguez-Díaz, 2015), validation of these questionnaires has helped professionals gather accumulative and comparable evidence, obtained at different times and from different places (Langhinrichsen-Rohling, 2005).

Even though each evaluation instrument contains an implicit definition of the behaviours and situations constituting partner violence, a number of systematic reviews have highlighted the triad comprised of physical, sexual and psychological violence as being the classification most commonly found in the literature (Hays \& Emelianchik, 2009; López-Cepero et al., 2015). Nevertheless, behaviours including monitoring, stalking and cyber stalking have led to a prominent fourth category within psychological aggressions: coercive control (Esquivel-Santoveña et al., 2013). A second, useful classification that overlaps with the pre- vious one distinguishes between overt and subtle aggression (Jones, Davidson, Bogat, Levendovsky, \& von Eye, 2005; Marshall, 1999). Thus, evaluations of partner violence should consider aggression in various spheres (sexual, physical...) and modalities (overt and subtle).

However, not all evaluation instruments are designed to provide quantitative results useful for research. In applied fields, it is common to find brief instruments designed to identify cases of violence, and screen at-risk people in order to be able to refer them to resources that will permit more detailed evaluation. Although there is no specific length for differentiating between a screening test and a full evaluation, various reviews propose lengths of 1-11 items to be answered on ordinal scales with 3 to 5 levels of frequency or with dichotomous yes/no answers (Arkins, Bergley, \& Higgins, 2016; López-Cepero, 2011).

The capacity for detection is affected by the types of violence considered (nearly all the screening methods reviewed evaluate some form of psychological and/or physical violence; fewer than half detect sexual aggressions, while only two include evaluations of coercive control; see Table 1). This capacity is also affected by the way the evaluation is applied among youths (self-disclosure is less prevalent in face-to-face interviews, more frequent in written evaluations, and most frequent in computerized tests, Hussain et al., 2015).

The majority of tools that have been validated at least once have been developed for gynaecology, traumatology or emergency services and to assess experiences of victimization of adult women by the opposite sex (Arkins et al., 2016; Haggerty, Hawkins \& Fontenot, 2011), yet none of the validations provide data on the effects of gender on test sensitivity (Arkins et al., 2016).

In light of this overview of the existing literature and given that screening tests are designed to detect abuse during routine processes (such as going to a doctor's appointment), it is striking that no screening instrument has been specifically developed for use in an educational setting, which could facilitate early detection of victimization. However, long evaluation instruments, with proven validity and reliability, do exist for teenage and youth samples (for a review, see López-Cepero et al., 2015). Among the available instruments, the Dating Violence Questionnaire (Spanish acronym CUVINO); López-Cepero, Fabelo, Rodríguez-Franco \& Rodríguez-Díaz, 2016) has been widely used across Latin-American and Spanish-speaking countries. However, all available tools are fairly lengthy ( 25 to 42 items), meaning that they are not ideal for use in early detection or as professional screening tools.

For all these reasons, the objective of this research project is to develop a short evaluation tool, based on DVQ, suitable for application to both sexes in a community setting, and to provide empirical evidence on its validity and reliability. 
Table 1 Screening tools available in the literature

\begin{tabular}{|c|c|c|c|c|c|c|c|}
\hline Tool & Reference & Phy & Psy & Sex & Con & Items & Rating \\
\hline AAS & McFarlane et al. (2001) & $\bullet$ & $\bullet$ & $\bullet$ & - & 3 & $\mathrm{Y} / \mathrm{N}$ \\
\hline ASI & Swahnberg et al. (2007) & $\bullet$ & - & • & - & 4 & $3 \mathrm{p}$. \\
\hline Do you feel...? & Peralta et al. (2003) & - & - & - & - & 1 & $\mathrm{Y} / \mathrm{N}$ \\
\hline HARK & Sohal et al. (2007) & $\bullet$ & • & $\bullet$ & - & 4 & $\mathrm{Y} / \mathrm{N}$ \\
\hline HITS & Sherin et al. (1998) & $\bullet$ & $\bullet$ & - & - & 4 & $5 \mathrm{p}$. \\
\hline OVAT & Ernst et al. (2004) & - & • & - & - & 3 & $\mathrm{Y} / \mathrm{N}$ \\
\hline PAI & Pan et al. (1997) & - & • & $\bullet$ & - & 11 & $4 \mathrm{p}$. \\
\hline PVS & Feldhaus et al. (1997) & $\bullet$ & $\bullet$ & - & - & 3 & $\mathrm{Y} / \mathrm{N}$ \\
\hline PVS+ & McMillan et al. (2006) & $\bullet$ & • & - & - & 5 & $\mathrm{Y} / \mathrm{N}$ \\
\hline SAFE-T & Fulfer et al. (2007) & - & • & - & - & 5 & $5 \mathrm{p}$. \\
\hline STaT & Paranjape et al. (2003) & $\bullet$ & $\bullet$ & - & - & 3 & $\mathrm{Y} / \mathrm{N}$ \\
\hline STaT+ & Wragle et al. (2008) & - & • & - & - & 7 & $\mathrm{Y} / \mathrm{N}$ \\
\hline UVPSP & Heron et al. (2003) & - & • & • & - & 5 & $\mathrm{Y} / \mathrm{N}$ \\
\hline WAST & Brown et al. (1996) & $\bullet$ & • & - & - & 7 & $3 \mathrm{p}$. \\
\hline WEB & Coker et al. (2001) & - & • & - & - & 10 & $6 \mathrm{p}$. \\
\hline
\end{tabular}

Compiled by the authors (based on Arkins et al., 2016; López-Cepero, 2011). Phy=physical; Psy=psychological/emotional; Sex=sexual; Con=control. AAS=Abuse Assessment Screen; ASI=Abuse Screening Inventory; Do you feel (safe at home)?; HARK=Humiliation, Afraid, Rape and Kick; HITS=Hurt, Insulted, Threatened or Screamed Questionnaire; OVAT=Ongoing Violence Assessment Tool; PAI=Partner Abuse Interview; PVS=Partner Abuse Screen; STaT=Slapped, Things and Threatened; UVPSP= Universal Violence Prevention Screening Protocol; WAST=Woman Abuse Screening Tool; WEB=Women's Experience with Battery Scale. +=expanded form.

\section{Study 1. Structure and reliability of Dating Violence Questionnaire - 8}

\section{Method}

Participants. The first study included 990 university students from a public university in Jalisco (Mexico), a metropolitan area with over 4.5 million inhabitants (INEGI, 2010). All the participants were adults, aged between 18 and 26 $(X=19.5 ; \mathrm{dt}=1.82$ years). The sample group was two thirds women and one third men (66\% and $34 \%$, respectively). All subjects signed consent forms after being informed of the study goals.

Instruments. This study obtained information from two questionnaires: a socio-demographic information sheet (including the sex and ages of the respondent and his/ her current or most recent partner), and the DVQ-8, a reduced version of the Dating Violence Questionnaire (DVQ; Cuestionario de Violencia de Novios -CUVINO in its original, Spanish version; López-Cepero et al., 2016). This eightitem instrument includes the fusion of contents from the eight scales found in previous DVQ validations (detachment, humiliation, sexual violence, coercion, physical violence, gender-based violence, emotional punishment, instrumental punishment), to be answered on a frequency scale of five levels (from $1=$ never to $5=$ nearly always). The DVQ-8 is therefore a screening instrument for routine evaluation. This instrument is included in the appendix.

Procedure. Participants provided information on their most recent (preferably current), stable (longer than one month) dating relationship. The evaluation was conducted through a web application, which provided information on the voluntary, anonymous and confidential nature of the study before proceeding to collect data. The link to the application was sent to students in the Social Work and Psychology Faculties. Contact information was provided to clarify any doubts that might arise at the time or later.

Two researchers who had participated in the validation of the original Spanish version of the DVQ (CUVINO, in Spanish) helped create the DVQ-8 in order to maximize the representativeness of its content (Rodríguez-Franco et al., 2010). Two consultants with extensive professional experience in the state of Jalisco also participated in order to adapt the phrasing of the items to the local context.

As for the statistical analyses, this study involved undertaking descriptive procedures (central tendency and dispersion measures and distribution analysis), comparative measures (Student $\mathrm{T}$ tests for independent groups, robust when the distribution does not fit normal distribution; ${ }^{*} p<.05$ ) and an estimation of effect size through $d$ (Cohen, 1988; negligible for values $d<.20$; small $d<.50$; moderate $d<.80$; large for $d=.80$ or over); obtained through SPSS Statistics 24. An exploratory factor analysis (EFA) was developed with version 10.3 of FACTOR software (Lorenzo-Seva \& Ferrando, 
2015), using parallel analysis based on polychoric matrices and Promin oblique rotation in two different steps. The first step was intended to determine the recommended number of factors, and the second to extract the factorial weights and goodness of fit to the factorial structure (in keeping with the recommendations by Ferrando \& Lorenzo-Selva, 2014). FACTOR provided EAP alpha reliability indices for the scale, suitable for ordinal data (EAP alpha > .700; Ferrando \& Lorenzo-Seva, 2016).

\section{Results}

An exploratory factor analysis was conducted to establish the internal structure of the DVQ-8, for both the whole sample, and men and women separately. In every case, FACTOR indicated that the solution of a single general factor was the best option for reaching suitable indicators of fit (Kaisser-Meyer-Olkin statistics equal to or over .85 and Global Fit Index-GFI=.99 in all cases). The factor, called partner violence, established high internal consistency (EAP alpha >.900) for the total test group as well as separately for men and women (Table 2).

A descriptive analysis was undertaken for measurements obtained by each item, both for the total test group, and for men and women separately. By means of a T test for independent samples (without assuming the equality of variances), statistical similarity was corroborated in the experience of victims of both sexes for six of the eight types of violence. In the case of physical and instrumental violence, a slightly higher mean was found among men; with a small effect size $(d>0.20)$. Total victimization was statistically similar for both groups, with a negligible effect size $(d=.13)$. This information is shown in Table 3.

\section{Study 2: concurrent and criteria validity for Dating Violence Questionnaire - 8}

\section{Method}

Participants. A total of 355 students at the university described earlier participated in a second study. Their

Table 2 Exploratory factor analysis for DVQ-8 in total sample, and by sex.

\begin{tabular}{lccc}
\hline & $\begin{array}{c}\text { Total } \\
(N=984)\end{array}$ & $\begin{array}{c}\text { Female } \\
(N=650)\end{array}$ & $\begin{array}{c}\text { Male } \\
(N=334)\end{array}$ \\
\hline Detachment & .568 & .558 & .596 \\
Humiliation & .834 & .831 & .839 \\
Emotional Punishment & .836 & .860 & .832 \\
Coercion & .696 & .685 & .736 \\
Gender Based & .808 & .841 & .800 \\
Sexual & .815 & .805 & .836 \\
Physical & .838 & .808 & .865 \\
Instrumental & .784 & .809 & .800 \\
KMO & .87 & .85 & .87 \\
Explained variance & $65.11 \%$ & $65.49 \%$ & $.93 \%$ \\
EAP Alpha & .933 & .935 & .938 \\
\hline
\end{tabular}

Table 3 Descriptive analysis for the whole sample and comparison of means by sex of respondent

\begin{tabular}{|c|c|c|c|c|c|c|c|c|c|}
\hline & \multicolumn{2}{|c|}{ Total } & \multicolumn{2}{|c|}{ Female } & \multicolumn{2}{|c|}{ Male } & \multicolumn{3}{|c|}{$T$ test } \\
\hline & $x$ & $\mathrm{dt}$ & $x$ & $\mathrm{dt}$ & $x$ & $\mathrm{dt}$ & $t$ & $p$ & $d$ \\
\hline Detachment & 1.90 & 1.160 & 1.93 & 1.205 & 1.85 & 1.070 & -.976 & .329 & .06 \\
\hline Humiliation & 1.36 & .825 & 1.35 & .813 & 1.40 & .852 & .900 & .368 & .06 \\
\hline Sexual & 1.10 & .455 & 1.08 & .398 & 1.13 & .551 & 1.436 & .152 & .11 \\
\hline Coercion & 1.42 & .892 & 1.41 & .859 & 1.46 & .957 & .843 & .400 & .06 \\
\hline Physical & 1.14 & .535 & 1.08 & .371 & 1.26 & .746 & 4.078 & $.000^{* * *}$ & $.33^{+}$ \\
\hline Gender B. & 1.18 & .585 & 1.16 & .563 & 1.21 & .627 & 1.254 & .210 & .09 \\
\hline Emot. Punish. & 1.24 & .707 & 1.21 & .664 & 1.30 & .783 & 1.839 & .066 & .13 \\
\hline Instrumental & 1.10 & .450 & 1.05 & .333 & 1.20 & .609 & 3.953 & $.000^{* * *}$ & $.32^{+}$ \\
\hline Total DVQ-8 & 10.46 & 3.87 & 10.29 & 3.62 & 10.81 & 4.30 & 1.830 & .068 & .13 \\
\hline
\end{tabular}

${ }^{* * *} p<.001 ;+d=$ small effect size. 
average age was $X=20.2$ years $(d t=1.80)$ and $75 \%$ were female. Just over half the participants $(52.7 \%)$ provided information on a current relationship.

Instruments. These were administered in four segments: The socio-demographic data sheet (described in study 1), the DVQ-8 (idem), a section on self-labelling the experience, and an inventory of prevalent symptoms and pathologies among university students (Health Issues Inventory-HII).

Information on labelling one's own experience was obtained in keeping with the method described by LópezCepero et al. (2016). This study only analysed information from one of the available labels: Have you felt or do you feel mistreated? The question was answered on a five-level frequency scale $(1=$ never, $5=$ almost always). Answers were classified into two levels: negative (never) and positive (sometimes/ often/ usually/ nearly always).

Lastly, a scale was administered to measure the occurrence of health issues throughout the partner relationship, selected from those proposed by Reig, Cabrero, Ferrer \& Richart (2001). The inventory included 20 items (e.g. How frequently do/did you suffer from headaches? ...lower abdominal pain? ...pain in your neck and shoulders? These questions were answered on a five-level frequency scale (1= never, $5=$ nearly always). During its validation with Mexican university students, the HII showed a single factor structure, with an estimated statistical reliability of .949 (Macías-Pérez, 2017). The EAP alpha value achieved a value of .923 in this study.

Procedure. The sampling method was identical to that described in study 1 , albeit with a different group of students. We asked participants to report on their current or most recent relationship. Statistical procedures included: descriptive analyses, comparison of averages (Student T tests for independent sample groups), C contingency coefficient for cross-tabulation $\left({ }^{*} p<.05\right)$ and estimated percentages of cases classified on the ROC curve (Receiver Operating Characteristic; * $p<.05$ ) using SPSS Statistics 24.

\section{Results}

The second study analysed the relation between scores from the DVQ-8, and the self-labelling of the mistreatment and health problems experienced by participants in their relationships.

First of all, a comparison was made of the averages for groups labelled as mistreated ( $25.8 \%$ of positive cases). Given the similar levels of victimization reported by men and women, analyses were conducted for the entire sample. The T test corroborated that people who labelled themselves as mistreated in their relationship obtained higher statistical averages for all forms of violence evaluated by the DVQ-8, with a large effect size for the whole scale (Table 4).

In order to establish a cut-off point to act as a risk marker, the ROC classification curve was analysed for the mistreatment label (positive or negative) in terms of the victimization experienced (area under curve $=.890 ;{ }^{* * *} p$ $<.001)$. Joint analysis of the correct classification of positive (sensitivity) and negative cases (specificity) showed that a cut-off point of between 9.5 and 10.5 points permitted correct categorization in a similar percentage of cases (approximately 80\%). Establishing 9.5 as the golden rule

Table 4 Comparison of averages for groups with and without mistreatment (without assuming equal variances).

\begin{tabular}{|c|c|c|c|c|c|c|c|c|}
\hline & $\begin{array}{l}\text { No perceived } \\
\text { maltreatment } \\
\quad(\mathrm{N}=253)\end{array}$ & $\begin{array}{l}\text { Perceived } \\
\text { maltreatment } \\
(\mathrm{N}=85)\end{array}$ & Dif. & $t$ & gl & $p$ & $d t$ & $d$ \\
\hline Detachment & 1.71 & 2.44 & 0.73 & 5.607 & 131 & $* * *$ & 1.016 & $.72^{++}$ \\
\hline Humiliation & 1.15 & 2.10 & 0.95 & 8.758 & 98 & $* * *$ & .747 & $1.27^{+++}$ \\
\hline Sexual & 1.04 & 1.36 & 0.32 & 4.121 & 91 & $* * *$ & .424 & $.75^{++}$ \\
\hline Coercion & 1.22 & 2.02 & 0.80 & 6.361 & 102 & $* * *$ & .829 & $.97^{+++}$ \\
\hline Physical & 1.03 & 1.42 & 0.39 & 4.996 & 91 & $* * *$ & .431 & $.90^{+++}$ \\
\hline Gender B. & 1.07 & 1.33 & 0.26 & 3.868 & 103 & $* * *$ & .415 & $.62^{++}$ \\
\hline Emot. Punish. & 1.11 & 1.67 & 0.56 & 5.485 & 105 & $* * *$ & .667 & $.83^{+++}$ \\
\hline Instrumental & 1.01 & 1.19 & 0.18 & 2.718 & 89 & $* *$ & .338 & $.54^{++}$ \\
\hline Total DVQ-8 & 9.36 & 13.64 & 4.28 & 10.207 & 99 & $* * *$ & 3.086 & $1.39^{+++}$ \\
\hline
\end{tabular}

${ }^{*} p<.05 ;{ }^{* *} p<.01 ;{ }^{* * *} p<.001 . d=$ size effect ${ }^{++}$moderate; ${ }^{+++}$large.

Table 5 “Mistreatment” label classification percentages for DVQ-8 results.

\begin{tabular}{lccccccccc}
\hline & \multicolumn{3}{c}{ Total sample } & \multicolumn{3}{c}{ Females } & \multicolumn{3}{c}{ Males } \\
\cline { 2 - 9 } & Sens. & Sp. & Total & Sens. & Sp. & Total & Sens. & Sp. & Total \\
\hline $\mathrm{CP}=8.5$ & $98.8 \%$ & $37.5 \%$ & $68.2 \%$ & $98.5 \%$ & $39.6 \%$ & $69.0 \%$ & $100 \%$ & $32.3 \%$ & $66.2 \%$ \\
$\mathrm{CP}=9.5$ & $91.8 \%$ & $68.0 \%$ & $79.9 \%$ & $89.2 \%$ & $70.6 \%$ & $79.9 \%$ & $100 \%$ & $60.0 \%$ & $80.0 \%$ \\
$\mathrm{CP}=10.5$ & $77.6 \%$ & $85.0 \%$ & $81.3 \%$ & $73.8 \%$ & $86.1 \%$ & $80.0 \%$ & $90.0 \%$ & $84.5 \%$ & $85.8 \%$ \\
$\mathrm{CP}=11.5$ & $64.7 \%$ & $90.5 \%$ & $77.6 \%$ & $63.1 \%$ & $91.4 \%$ & $77.3 \%$ & $70.0 \%$ & $87.7 \%$ & $78.8 \%$ \\
\hline
\end{tabular}

$\mathrm{CP}=$ cut-off point; Sens. $=$ Sensitivity; Sp. $=$ Specificity. Recommended cut-off point $=10.5$ 
enabled us to maintain a high percentage of true positives, yet with discrete specificity and $47 \%$ of participants proposed as potential victims. A cut-off point of 10.5 obtained a higher percentage of correct classification (81\%), with $30.8 \%$ of positive cases (see Table 5 ). The proportion of positive cases was similar in both sexes $(C=.056 ; p=.306)$.

Lastly, the relationship between victimization and health issues described by the respondents was tested. As regards correlation, the existence of a positive and significant relationship was proven between total victimization (DVQ-8) and health problems experienced (HII) (Spearman's Rho $\left.=.418 ;{ }^{* * *} p<.001\right)$. A comparison was also made of the health problems among the two groups in relation to their DVQ-8 scores: below 10.5 (regarded as negative cases) and 10.5 and over (regarded as positive cases). In the $T$ test, the group of positive cases showed a greater prevalence in 19 of the 20 signs and symptoms evaluated $\left({ }^{*} p<.05 ; d=[.24-.81]\right)$. For the total HII score, these differences were significant $\left({ }^{* * *} p<.001\right.$ and large size $(d=.80)$. In terms of the possible effect of the respondent's sex on results, a greater rate of symptomatology was found in the female group rather than the male group $\left({ }^{* *} p=.007 ; d=.39\right)$; significant differences were also corroborated between the groups defined by the DVQ-8, with a moderate-sized effect among women $\left({ }^{* * *} p<\right.$ $.001 ; d=.67)$ and a large effect size among men $\left({ }^{* *} p<.01\right.$; $d=1.10$ ). These figures are included in table 6 .

\section{Conclusions and discussion}

The main purpose of this study was to provide psychometric information on a new measurement instrument, the DVQ-8, designed for the screening and early detection of violence in young couples in educational settings. The exploratory factor analysis, developed on the basis of Ferrando and Lorenzo-Seva's proposal (2014), showed the existence of a single factor that was able to explain more than $65 \%$ of the variance, with a reliability rate of over .900 . Moreover, the ROC curve analysis allowed for a cut-off point that correctly classifies approximately $80 \%$ of cases (both positive and negative). These results were valid for both men and women, addressing a challenge mentioned in previous literature (Arkins et al., 2016).

Evidence of the instrument's validity rests on three pillars. First of all, the DVQ-8 is based on a previously validated tool, in which the definition of violence includes both physical and sexual violence, coercive control, and various forms of psychological violence, both direct and indirect, meeting the needs raised in the literature (EsquivelSantoveña et al., 2013; Marshall, 1999). The second is that levels of sensitivity and specificity were similar to or greater than those described by other more commonly used tools such as self-reports and the golden rule (Arkins et al., 2016).

Table 6 Descriptors, comparisons and effect size for the Health Issues Inventory in groups with and without victimization.

\begin{tabular}{|c|c|c|c|c|c|c|}
\hline Sign & $\begin{array}{l}\text { Low victimization } \\
\text { (DVQ -8 < 10.5) }\end{array}$ & $\begin{array}{l}\text { High victimization } \\
\text { (DVQ }-8 \geq 10.5 \text { ) }\end{array}$ & $\mathrm{dt}$ & $t$ & $p$ & $d$ \\
\hline 1. Lower abdominal pain & 1.93 & 2.26 & 1.15 & 2.336 & * & $.29+$ \\
\hline 2. Hand tremors & 1.56 & 2.02 & .988 & 3.856 & $* * *$ & $.47+$ \\
\hline 3. Depressed mood & 2.14 & 3.11 & 1.145 & 7.274 & $* * *$ & $.85+++$ \\
\hline 4. Constipation & 1.86 & 2.22 & 1.153 & 2.583 & * & $.31+$ \\
\hline 5. Difficulty concentrating & 2.47 & 3.26 & 1.208 & 5.835 & $* * *$ & $.65++$ \\
\hline 6. Nightmares & 1.63 & 2.21 & 0.988 & 4.623 & $* * *$ & $.59++$ \\
\hline 7. Back/spinal pain & 2.18 & 2.75 & 1.312 & 3.668 & $* * *$ & $.43+$ \\
\hline 8. Neck/shoulder pain & 2.07 & 2.72 & 1.268 & 4.130 & $* * *$ & $.51++$ \\
\hline 9. Nervousness & 1.88 & 2.58 & 1.169 & 4.810 & $* * *$ & $.60++$ \\
\hline 10. Mood swings & 2.37 & 3.13 & 1.234 & 5.287 & $* * *$ & $.62++$ \\
\hline 11. Fears /phobias & 1.43 & 2.05 & .981 & 4.656 & $* * *$ & $.63++$ \\
\hline 12. Diarrhea & 1.43 & 1.76 & .835 & 3.000 & ** & $.40+$ \\
\hline 13. Palpitations/dizziness & 1.61 & 2.05 & 1.031 & 3.411 & $* *$ & $.43+$ \\
\hline 14. 14. Sleep (quality) & 2.06 & 2.97 & 1.303 & 5.697 & $* * *$ & $.70++$ \\
\hline 14. Neuro-dermatitis & 1.09 & 1.21 & .495 & 1.823 & - & $.24+$ \\
\hline 16. Overweight & 1.46 & 1.82 & 1.044 & 2.632 & $* *$ & $.34+$ \\
\hline 17. Accidents (traffic...) & 1.18 & 1.33 & .575 & 1.991 & * & $.26+$ \\
\hline 18. Headaches/migraines & 1.80 & 2.37 & 1.199 & 3.701 & $* * *$ & $.48+$ \\
\hline 19. Gastritis/ulcers & 1.67 & 2.16 & 1.172 & 3.297 & $* *$ & $.42+$ \\
\hline 20. Insomnia & 1.76 & 2.78 & 1.252 & 6.638 & $* * *$ & $.81+++$ \\
\hline Total Health Issues Inventory & 35.59 & 46.66 & 13.909 & 6.544 & $* * *$ & $0.80+++$ \\
\hline
\end{tabular}

${ }^{*} p<.05 ;{ }^{* *} p<.01 ;{ }^{* * *} p<.001$. Effect size d: ${ }^{+=}$small; ${ }^{++}$moderate; ${ }^{+++}$large. 
The third is that the groups defined by the selected cutoff point (10.5) showed large, significant differences in the health problems experienced by the participants, pointing to a direct relationship between victimization and negative health outcomes.

An analysis of the frequency of victimization detected by the instrument yields two conclusions. The first is that the most frequent type of abuse (detachment and coercion) corresponds to less direct (subtle) aggression. More direct (overt) violence (physical and sexual), however, is more easily recognized, yet less common. These results coincide with the findings of the complete version of the DVQ (López-Cepero et al., 2016; Rodríguez-Franco et al., 2010) and underscore the need to include information on more subtle types of violence in prevention and awareness campaigns. Detection of these subtle types of violence allow relationships to be terminated before they escalate into abusive relationships. Secondly, the statistical similarity found for both sexes is striking. These results are compatible with those described in the literature as useful for research undertaken in sample communities (as opposed to selected samples such as those obtained from shelters for abuse survivors or penitentiary centres; Langhinrichsen-Rohling et al., 2012). However, and beyond discussing the different implications of abuse for men and women, these findings highlight a matter of concern: the high percentage of people who engage in relationships in which interactions include violence. Even if we begin with the premise that violence has a lower impact on men, the fact that they participate in relationships in which scorn, control and blows are used implies a risky context for the development of unhealthy relationships. This information should therefore serve as the basis for developing preventive intervention methods for a broad population spectrum.

This study has a number of constraints that may make it difficult to generalize its conclusions. First, participants were drawn from a single geographical location (Central Mexico), meaning that further studies in other regions are required in order to prove the invariance of the findings. Likewise, all the participants were enrolled at university, thereby excluding adolescents and other young adults who are unable to access higher learning from participating in the study. Nevertheless, these limitations are offset by the following: (1) the percentage of young adults enrolled at this level of education in Mexico has increased rapidly over the past two decades (from $10 \%$ to $16 \%$ in the last INEGI evaluation, 2010) and (2) most screening instruments are used in specific hospital settings, where the percentage of the population attended is probably lower than that of the education sector.

A closer look at the contributions of this study shows that the DVQ-8 has yielded good psychometric evidence in a wide range of young adults, both men and women (who share a cut-off point), regardless of the participants' sexual orientation, which is not covered by other tools (Arkins et al., 2016). Likewise, the DVQ-8 offers separate indicators for the primary types of aggression including sexual, physical and psychological violence, coercive control, and subtle forms such as detachment and emotional punishment overlooked in earlier instruments. Thus, even though this text focuses on the usefulness of the tool for screening, the quantitative results of the DVQ- 8 could also be used to shape the contents of an intervention program for specific groups (e.g. a class), or even as a brief (although valid and reliable) option for evaluating victim experiences for research projects in which dating violence is relevant, but not central.
For all the above reasons, the DVQ-8 contains sufficient guarantees to be included in professional use by educators to screen for high-risk cases at a low cost. It permits the early detection of victimization in young couples and makes it easier to refer victims to resources that could help them resolve their situation quickly and safely.

\section{Referencias}

Arkins, B., Begley, C., \& Higgins, A. (2016). Measures for screening for intimate partner violence: A systematic review. Journal of Psychiatric and Mental Health Nursing. 23, 217-235. http://dx. doi.org/10.1111/jpm.12289

Brown, J.B., Lent, B., Brett, P.J., Sas, G., \& Pederson, L.L. (1996). Development of the woman abuse screening tool for use in family practice. Family Medicine, 28, 422-428.

Cohen, J. (1988). Statistical Power Analysis for the Behavioral Sciences. ( $2^{\text {nd }}$ ed). NJ, EEUU: Erlbaum.

Coker, A.L., Pope, E.B.O., Smith, P.H., Sanderson, M., \& Hussey, J.R. (2001). Assessment of clinical partner violence screening tools. Journal of the American Medical Women's Association, 56, 19-23.

Cortaza, L., Mazadiego, T., \& Ruiz, S. (2011). Prevalencia de violencia en el noviazgo en estudiantes preuniversitarias de $\mathrm{Mi}$ natitlán, México. Revista Exploratoris, 2, 13-18.

Costa, D. \& Barros, H. (2016). Instruments to assess intimate partner violence: A scoping review of the literature. Violence and Victims, 31, 591-621. http://dx.doi.org/10.1891/0886-6708.VVD-14-00122

Desmarais, S.L., Reeves, K.A., Nichols, T.L., Telford, R.P., \& Fiebert, M.S. (2012). Prevalence of physical violence in intimate relationships, part 1: Rates of male and female victimization. Partner Abuse, 3, 140-169. http://dx.doi.org/10.1891/19466560.3.2.140

Ernst, A.A., Weiss, S.J., Cham, E., \& Marquez, M. (2002). Comparison of three instruments for assessing ongoing intimate partner violence. Medical Science Monitor, 8, 197-201.

Esquivel-Santoveña, E.E., Lambert, T.L., \& Hamel, J. (2013). Partner abuse worldwide. Partner Abuse, 4, 6-75. http://dx.doi. org/10.1891/1946-6560.4.1.6

Feldhaus K.M., Kozoil-Mclain J., Amsbury H.L., Norton, I.M., Lowestein, S.R., \& Abbot, J.T. (1997) Accuracy of 3 brief screening questions for detecting partner violence. The Journal of the American Medical Association, 277, 1357-1361. http://dx.doi. org/10.1001/jama.1997.03540410035027

Ferrando, P.J. \& Lorenzo-Seva, U. (2014). El análisis factorial exploratorio de los ítems: Algunas consideraciones adicionales. Anales de Psicología, 30, 1170-1175. http://dx.doi.org/10.6018/ analesps.30.3.199991

Ferrando, P.J. \& Lorenzo-Seva, U. (2016). A note on improving EAP trait estimation in oblique factor-analytic and item response theory models. Psicológica, 37, 235-247.

Fulfer J.L., Tyler J.J., Choi N.J., Young, J.A., Verhulst, S.J., \& Dorsey, J.K. (2007) Using indirect questions to detect intimate partner violence the SAFE-T Questionnaire. Journal of Interpersonal Violence 22, 238-249. http://dx.doi. org $/ 10.1177 / 0886260506295814$

Haggerty, L.A., Hakins, J.W., \& Fontenot, H. (2011). Tools for screening interpersonal violence: State of the science. Violence and Victims, 26, 725-737. http://dx.doi.org/10.1891/08866708.26.6.725

Hays, D.G., \& Emelianchik, K. (2009). A content analysis of intimate partner assessments. Measuring and Evaluation in Counseling and Development, 42, 139-152. http://dx.doi. org/10.1177/0748175609344090 
Heron, S.L., Thompson, M.P., Kackson, E., \& Kaslow, N.J. (2003). Do responses to an intimate partner violence screen predict scores on a comprehensive measure of intimate partner violence in low-income black women? Annals of Emergency Medicine, 42, 483-491. http://dx.doi.org/10.1067/mem.2003.397

Hussain, N., Sprague, S., Madden, K., Hussain, F.N., Pindiprolu, B., \& Bhandari, M. (2015). A Comparison of the types of screening tool administration methods used for the detection of intimate partner violence: A systematic review and meta-analysis. Trauma, Violence and Abuse, 16, 60-69. http://dx.doi. org/10.1177/1524838013515759

Instituto Mexiquense de la Juventud (2013). Prevención de la violencia en el noviazgo: índice de violencia en el noviazgo en jóvenes mexiquenses. Retrieved from http://www.ipomex.org. $\mathrm{mx} / \mathrm{ipo} / \mathrm{archivos} /$ downloadAttach/931331.web

INEGI (2010). México en cifras: Información nacional, por entidad federativa y municipios. Retrieved from http://www3.inegi. org. $\mathrm{mx} /$.

INEGI (2017). Resultados de la encuesta nacional sobre la dinámica de las relaciones en los hogares (ENDIREH) 2016. Boletín 379/17. Retrieved from http://bdsocial.inmujeres.gob.mx/.

Jones, S., Davidson II, W.S., Bogat, G.A., Levendovsky, A., \& von Eye, A. (2005). Validation of the subtle and overt psychological abuse scale: An examination of construct validity. Violence and Victims, 20, 407-416. http://dx.doi. org/10.1891/088667005780927575

Langhinrichsen-Rohling, J. (2005). Top 10 greatest "hits": Important findings and future directions for intimate partner violence research. Journal of Interpersonal Violence, 20(1), 108-118. http://dx.doi.org/10.1177/0886260504268602

Langhinrichsen-Rohling, J., Misra, T.A., Selwyn, C., \& Rohling, M.L. (2012). Rates of bidirectional versus unidirectional intimate partner violence across samples, sexual orientations, and races/ethnicities: A comprehensive review. Partner Abuse, 3, 199230. http://dx.doi.org/10.1891/1946-6560.3.2.199

López-Cepero, J. (2011). Victimización en el noviazgo de personas adolescentes y jóvenes: Evaluación, prevalencia y papel de las actitudes [Victimization among adolescents and youths: Assessment, prevalence and role of attitudes]. Dissertation thesis. (Dissertation thesis, University of Seville, Spain). Retrieved from http://hdl.handle.net/11441/26891

López-Cepero, J., Fabelo, H.E. Rodríguez-Franco, L., \& Rodríguez-Díaz, F.J. (2016). The dating violence questionnaire: Validation of the Cuestionario de Violencia de Novios using a college sample from the United States. Violence and Victims, 31, 438-456. http://dx.doi.org/10.1891/0886-6708.VV-D-14-00077

López-Cepero, J., Rodríguez-Franco, L., \& Rodríguez-Díaz, F.J. (2015). Evaluación de la violencia de pareja: Una revisión de instrumentos de evaluación conductual. Revista Iberoamericana de Diagnóstico y Evaluación Psicológica, 40, 37-50.

Lorenzo-Seva, U. \& Ferrando, P.J. (2015). FACTOR 10.3 for Windows (64 bits). Spain: Rovira i Virgili University. Retrieved from http://psico.fcep.urv.es/

López, F., Moral, J., Díaz, R., \& Cienfuegos, Y. I. (2013). Violencia en la pareja. Un análisis desde una perspectiva ecológica. Ciencia Ergo Sum, 20(1), 6-16.

Loving, T.J. \& Slatcher, R.B. (2013). Romantic relationships and health. In J.A. Simpson \& L. Campbell (Eds.). The Oxford Handbook of Close Relationships (pp. 617-637). New York: Oxford University Press. http://dx.doi.org/10.1093/oxford$\mathrm{hb} / 9780195398694.001 .0001$

Macías-Pérez, M. (2017). Efecto del taller de promoción de relaciones de pareja saludables en universitarios: Evaluación y aplicación [Effects of a promotion program on healthy partner relationships among college students: Assessment and implementation]. Unpublished master's thesis. Universidad de Guadalajara, Mexico.
Macmillan, H.L., Wathen, C.N., Jamieson, E., Boyle, M., McNutt, L.A., Lent, B., Webb, M., \& McMaster Violence Against Women Research Group. (2006). Approaches to screening for intimate partner violence in health care settings. The Journal of the American Medical Association, 296, 530-536. http://dx.doi. org/10.1001/jama.296.5.530

Marshall, L.L. (1999). Effects of men's subtle and overt psychological abuse on low-income women. Violence and Victims, 14, 69-88.

Mcfarlane, J., Hughes, R.B., Nosek, M.A., Groff, J.Y., Swedlend, N., \& Mullen, P.D. (2001). Abuse assessment screen-disability (AAS-D): measuring frequency, type, and perpetrator of abuse toward women with physical disabilities. Journal of Women's Health \& Gender-Based Medicine, 10, 861-866. http://dx.doi. org/10.1089/152460901753285750

Pan, H., Ehrensaft, M., Heyman, R., O'Leary, K.D., \& Schwartz, R. (1997). Evaluating domestic partner abuse in a family practice clinic. Family Medicine, 29, 492-495.

Paranjape, A. \& Liebschutz, J. (2003) STaT: a three-question screen for intimate partner violence. Journal of Women's Health, 12, 233-239. http://dx.doi.org/10.1089/154099903321667573

Peña, F., Zamorano, B., Hernández, G., Hernández M. L., Vargas, J. I., \& Parra, V. (2013). Violencia en el noviazgo en una muestra de jóvenes mexicanos. Revista Costarricense de Psicología, 32(1), 27-40.

Peralta, R.L. \& Fleming, M.F. (2003). Screening for intimate partner violence in a primary care setting: the validity of "feeling safe at home" and prevalence results. Journal of the American Board of Family Medicine, 16, 525-532. http://dx.doi. org/10.3122/jabfm.16.6.525

Reig, A., Cabrero, J., Ferrer, R.I., \& Richart, M. (2001). La calidad de vida y el estado de salud de los estudiantes universitarios. Spain: University of Alicante. Retrieved from http://www.biblioteca.org.ar/libros/88711.pdf.

Rodríguez-Franco, L., López-Cepero, J., Rodríguez-Díaz, F.J., Bringas, C., Antuña, A., \& Estrada, C. (2010). Validación del cuestionario de violencia entre novios (CUVINO) en jóvenes hispanohablantes: Análisis de resultados en España, México y Argentina. Anuario de Psicología Clínica y de la Salud, 6, 45-52.

Sherin, K.M., Sinacore, J.M., Li, X-Q., Zitter, R.E., \& Shakil, A. (1998). HITS: a short domestic violence screening tool for use in a family practice setting. Family Medicine, 30, 508-512.

Sohal, H., Eldridge, S., \& Feder, G. (2007). The sensitivity and specificity of four questions (HARK) to identify intimate partner violence: a diagnostic accuracy study in general practice. BMC Family Practice, 8, 49-58. http://dx.doi.org/10.1186/14712296-8-49

Sosa, I. A. \& Menkes, C. (2016). Amarte duele. La violación sexual en las relaciones de noviazgo. Un análisis de sus determinantes sociales. Papeles de Población, 22(87), 43-62.

Swahnberg, K. \& Wijma, K. (2007). Validation of the abuse screening inventory (ASI). Scandinavian Journal of Public Health, 35, 330-334. http://dx.doi.org/10.1080/14034940601040759

Uchino, B.N. (2006) Social support and health: A review of physiological processes potentially underlying links to disease outcomes. Journal of Behavioral Medicine, 29, 377-387. http:// dx.doi.org/10.1007/s10865-006-9056-5

Wrangle, J., Fisher, J.W., \& Paranjape, A. (2008). Ha sentido sola? Culturally competent screening for intimate partner violence in Latina Women. Journal of Women's Health, 17, 261-268. http://dx.doi.org/10.1089/jwh.2007.0394 


\section{ANNEX}

\section{Dating Violence Questionnaire - 8}

In this section we ask one thing:

If the situation has arisen for you in your partner relationship and how frequently (refer only to one relationship).

Please tick one of the 5 options in the right-hand column for each of the following statements.

En este apartado te preguntamos una cosa:

Si te han ocurrido, y con qué frecuencia, cada una de las siguientes situaciones en la relación de pareja (piensa en una misma relación).

Por favor, marca una de las 5 opciones de la columna derecha para cada una de las siguientes afirmaciones.

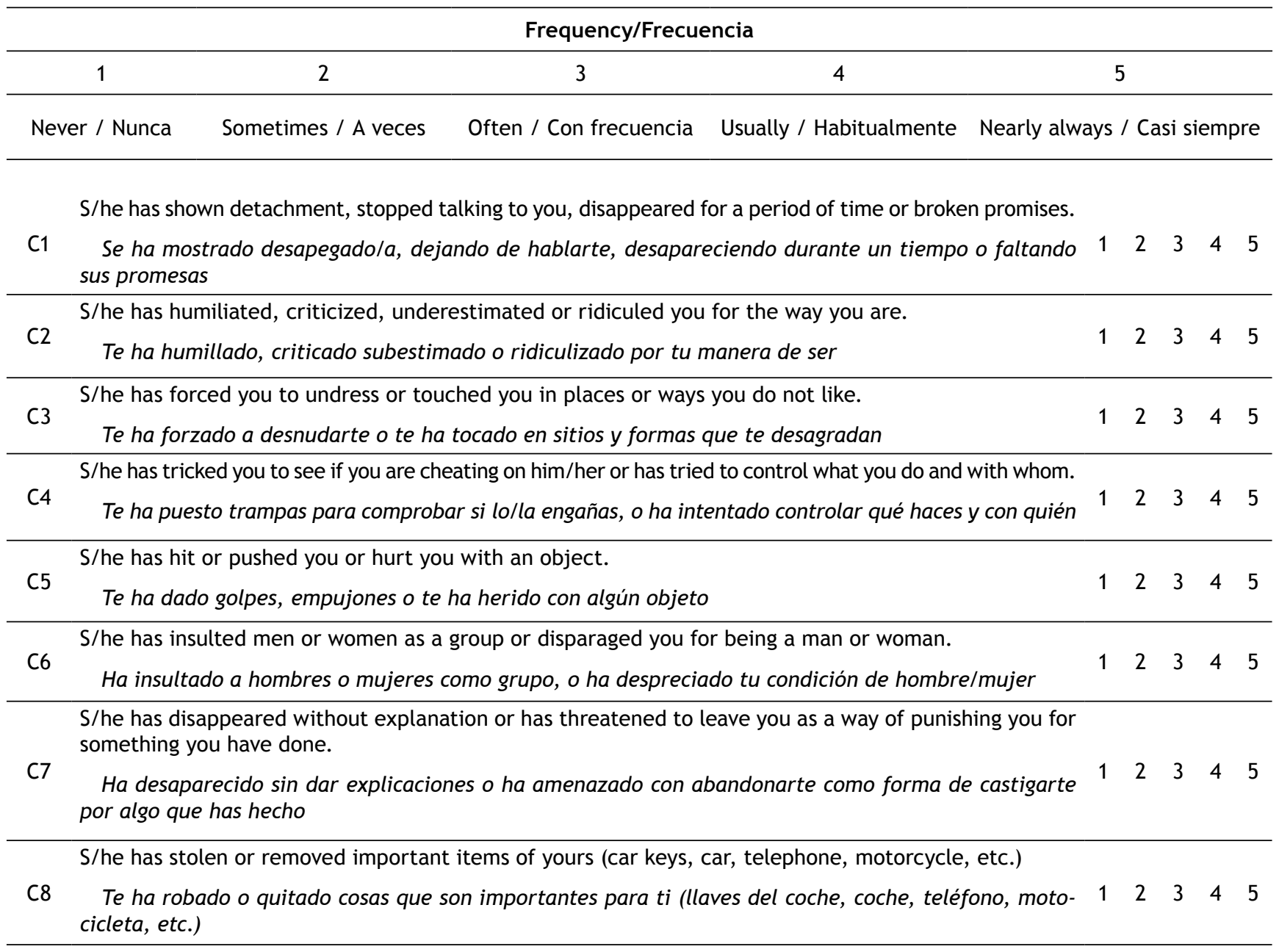

